Diabetologia 4, 148-149 (1972)

(C) by Springer-Verlag 1972

\title{
Influence of Isolated Insulin Antibodies on the Insulin Secretion of the Islets of Langerhans in Vitro
}

\author{
M. ZiegleR, H.J. HaHN and D. KLaTT \\ Zentralinstitut für Diabetes ,Gerhardt Katsch“, Karlsburg, DDR \\ Received: December 3, 1971, accepted: December 23, 1971
}

Summary. Mouse islets of Langerhans, isolated by microdissection after treatment with collagenase, were incubated either with pure insulin antibodies (IAB) which were prepared by immune precipitation, or with exogenous insulin. Insulin release was enhanced with increased concentrations of IAB and was inhibited by exogenous insulin. The results suggest that it was not the insulin per se, but probably its biological effect on the $\beta$-cells that influenced insulin secretion.

Key words: Isolated islets of Langerhans, insulin secretion, feed-back mechanism, isolated insulin antibodies.
Addition of exogenous insulin inhibits glucose stimulated insulin secretion in vitro $[1,2]$ but stimulation of insulin release after injection of anti-insulin serum in vivo is described $[3,4]$.

In earlier experiments we found a dose-dependent increase of total extractable IRI after incubation of islets with isolated insulin antibodies (IAB) [5]. The present studies were carried out in order to investigate the influence of insulin antibodies on the free and bound insulin content in the medium.

\section{Material and methods}

Ten isolated pancreatic islets [6] from normal mice were incubated for $30 \mathrm{~min}$, after a preincubation period of $30 \mathrm{~min}$, at $37^{\circ} \mathrm{C}$ in $3 \mathrm{ml}$ of Krebs-Ringer bicarbonate buffer, $\mathrm{pH}$ 7.4, containing bovine serum albumin, $2 \mathrm{mg} / \mathrm{ml}$ (Behring-Werke, Marburg) and glucose, $2 \mathrm{mg} / \mathrm{ml}$ (Fluka, Buchs), gassed with $95 \% \mathrm{O}_{2}$ and $5 \% \mathrm{CO}_{2}$. There were added either different concentrations of mouse insulin $(0 ; 170$ or $800 \mu \mathrm{U} / \mathrm{ml})$ or increased concentrations of pure IAB $(0,1.33$ or $4 \mathrm{mg} /$ $\mathrm{ml}$ ). The pure IAB were prepared by immune precipitation of goat anti-insulin serum with insulin. The immune complex was dissolved in glycine buffer, pH 2.4, and the IAB separated from insulin by gel filtration on Sephadex G-100. The isolated IAB were immunoelectrophoretically pure and belong to the IgG class [7]. The total and free immunoreactive insulin (IRI) of the medium were assayed according to Heding [8]. The insulin secretion was calculated as the difference $\operatorname{IRI}_{t=30 \mathrm{~min}}-\mathrm{IRI}_{t=0}$. The significance of the results was checked by the Student $t$-test.

\section{Results}

The influence of added exogenous species-equal insulin and of pure isolated IAB on the glucosestimulated insulin secretion is illustrated in Fig. 1. The inhibition of the insulin release by insulin $(800 \mu \mathrm{U} / \mathrm{ml})$ could be reproduced under these conditions $(p<0.01)$. With increased concentrations of isolated IAB the secretion of total IRI was enhanced $(p<0.01)$ whereas the content of free insulin was decreased $(p<0.01)$.

\section{Discussion}

The inhibition of glucose-stimulated insulin secretion of pancreatic islets by exogenous insulin and the enhancement of insulin output in the presence of isolated pure IAB support the hypothesis of a negative feed-back mechanism of regulation of insulin secretion [2].

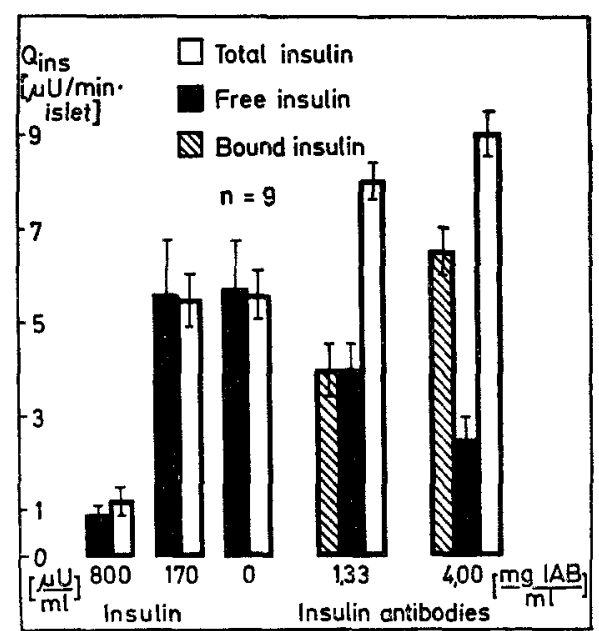

Fig. 1. Influence of exogenous insulin and insulin antibodies upon insulin release by isolated islets (mean \pm SEM, $n=9$ )

The present findings differ from the results of Malaisse et al. [9], who found that neither insulin nor guinea pig anti-insulin serum have a direct affect upon insulin secretion. However, the conditions of ex- 
periments are different, e.g. Malaisse et al. [9] employed anti-insulin serum while we used pure isolated IAB.

A non-specific effect of protein upon insulin secretion can be excluded since normal immunoglobulin did not significantly increase the insulin output. Furthermore, the insulin secretion of islets incubated with IAB could be stimulated by glucose and glibenclamide in a further incubation [10], suggesting that the islets were intact after IAB-treatment.

If there is a feed-back inhibition, the one might expect that in the presence of IAB insulin would be secreted until the $\mathrm{IAB}$ are saturated and the concentration of free insulin reaches that attained in the absence of IAB. As illustrated in Fig. 1 however, the level of free insulin decreases with enhanced IABconcentration. In other experiments we recently found [11], in investigations of insulin binding and insulin neutralizing capacity of isolated IAB, that the bound insulin has frequently some biological activity. This finding could explain why, during incubation of isolated islets with increased concentration of IAB, there is no constant content of free insulin. Perhaps only biological insulin activity, resulting from free and bound insulin, remains constant.

The present results suggest that it is not insulin, per se, but probably its hormonal effect on the B-cells, that influences the insulin secretion.

\section{References}

1. Sodoyez, J.C., Sodoyez-Goffaux, F., Foa, P.P.: Evidence for an insulin-induced inhibition of insulin release by isolated islets of Langerhans. Proc. Soc. exp. Biol. (N. Y.) 130, 568-571 (1969).

2. Iversen, J., Miles, D.W.: Evidence for a feed-back inhibition by insulin in physiological concentrations of insulin secretion in the isolated perfused canine pancreas. Diabetes 20, 1-9 (1971).

3. Wagle, S.R.: Studies on biosynthesis and catabolism of insulin. Biochim. Biophys. Acta 107, 524-525 (1965).

4. Logothetopoulos, J.: Electron microscopy of the pancreatic islets stimulated by insulin antibody. Canad. J. Physiol. Pharmacol. 46, 407-410 (1968).

5. Hahn, H.-J., Ziegler, M., Ziegler, B., Michael, R.: Untersuchungen zur Frage der Eigenhemmung der Insulinsekretion in vitro. in Diabetes mellitus. Hrsg. J. Magyar and A. Beringer, Verlag Wiener Akad., $661-664$ (1971).

6. - Lippmann, H.-G., Schultz, D.: Verhalten dor Langerhans'schen Inseln des Pankreas in vitro. I. Präparationstechnik und Methodenkritik. Acta biol. med. german. 25, 421-431 (1970).

7. Ziegler, M., Knospe, S.: The neutralizing and increasing effect of isolated insulin antibodies on biological activity of crystalline insulin. Internat. Symposium on Diabetes, Sofia 1970.

8. Heding, L.G.: Determination of free and antibodybound insulin in insulin treated diabetic patients. Horm. Metab. Res. 1, 145-146 (1969).

9. Malaisse, W.J., Malaisse-Lagae, F., Lacy, P.E., Wright, P.H.: Insulin secretion by isolated islets in presence of glucose, insulin and anti-insulin serum. Proc. exp. Biol. 124, 497-500 (1967).

10. Hahn, H.-J., Ziegler, M.: Influence of isolated insulin antibodies an insulin secretion in vitro. Europ. Ass. Study Diabetes 7th Annual Meeting Southhampton 1971 .

11. Ziegler, M., Knospe, S.: Vergleichende Untersuchungen zur Insulinbindungs- und Neutralisierungskapazität isolierter Insulinantikörper. Erg. Experim. Med., in press (1971).

Dr. rer. nat. Manfred Ziegler

Dr. med. Hans-J. Hahn

MTA Dietmar Klatt

Central Institute for Diabetes

"Gerhardt Katsch"

DDR-2201 Karlsburg 